\title{
DEVELOPMENT WITHIN THE EXPERIENCE ECONOMY - KEY AREAS FOR SUCCESSFUL GROWTH?
}

\author{
Received 3 April 2017 \\ Anna Sörensson \\ Revised 22 June 2017 \\ 1 August 2017 \\ Accepted 2 August 2017 \\ https://doi.org/10.20867/tosee.04.36
}

\begin{abstract}
Purpose - This paper discusses the experience economy and key areas for growth within this field. The aim for this paper was to investigate how business people see potential for growth within the experience economy.

Methodology -The data was collected using an electronic questionnaire with 17 questions, with both open and closed questions. The study was conducted in the county of Jämtland in Sweden. The county Administrative Board had a database with e-mail addresses to companies which was used to send the questionnaire. 136 business people answered the electronic questionnaire. The data was then analysed and categorized with an interpretative approach.

Findings - The conclusion is that there are several key factors that are of importance for growth within the experience economy namely entrepreneurs (1), co-operation (2), infrastructure (3), businessmen/women (4), resources (5) and support from the public sector (6). There is also a relation between the most important area within creative industry and the region's main industry area. In the area where this study was conducted, the respondents believed that growth could mainly be achieved in that field (e g tourism).

Originality of the research - The theoretical contribution from this paper is a clear connection between what is the most important area within the experience economy to a particular region. The practical implications are that there is a great potential for growth, especially with a focus on the areas discussed by the business people in this paper.
\end{abstract}

Keywords Experience economy, Creative industries, Development, Growth, Growth factors.

\section{INTRODUCTION}

In today's society a greater focus is directed against experiences which could lead to that experience industry can play an increasing role in community development. Today, the experience industry is of great importance both economically and socially, and researchers are discussing that we are moving from an information society to an experience society (Almqvist, Engstrom and Olausson, 2000). The experience industry is a concept that has been discussed and there are several different concepts used interchangeably as the business experience, creative industries, cultural industries and more. The definition commonly used in Sweden, and used in the following article is the Knowledge Foundation's: "Industry experience includes people and businesses with a creative approach that has as its main task to create and/or deliver experiences in some form" (The knowledge foundation, 2002). The experience industry in Sweden is a relatively new concept but is well established in the United States, primarily through 
ToSEE - Tourism in Southern and Eastern Europe, Vol. 4, pp. 557-566, 2017

A. Sörensson: DEVELOPMENT WITHIN THE EXPERIENCE ECONOMY - KEY AREAS FOR

the U.S. superiority in the film industry. In Great Britain, industry experience has many different synonymous names as Experience Economy, Experience Marketing, Creative Industries, Cultural Economy and Cultural Sectors (Abbasian and Bildt, 2007). In Britain, the concept of "cultural industries" had a great impact and can now be considered well established. In Sweden, the development of experience economy has been driven primarily by the Knowledge Foundation. Discussions from public organization in Sweden has often touched on the economic importance of the experience industry, although there are still difficulties in measuring the industry. It has been difficult to define what to include and what to exclude. Previous research have focused on for instance how entrepreneurship can be stimulated with artists, performers and creators (Gustafsson, 2008). The experience industry has experienced strong growth and currently accounts for approximately 5\% of Sweden's GDP and employs around 280000 people. Several studies show an increased growth in the future. Kolmodin et al (2008) discusses how the experience industry will achieve growth. Previous research has focused on what the concept of industry experience to include. The aim for this paper is to explore how business people believe growth can be achieved within the experience economy. This will be further examined in the following research questions:

RQ1: Which are the driving forces for development and growth within the experience economy?

RQ2: How does a region's main area within the experience economy influence the growth potential?

\section{EXPERIENCE ECONOMY qI}

Pine and Gilmore (1999; 2002a; 2002b) argue that customers nowadays seek experience and are therefore no longer just consuming products and services. Tourism is seen as stages of experience where the tourists look for unique experiences when travelling to destinations. The idea is to create value added memorable experiences for the tourists (Richards, 2001; Oh, Fiore and Jeoung, 2007). In today's society, there is a greater focus directed towards experiences, which should lead to the experience economy playing an increasingly important role in society. The experience industry includes people and businesses with a creative approach that has as its main task to create and/or deliver experiences in any form (Almqvist and Daal, 2002). Today there is no single definition for the experience economy, whether at national, EU, or international level. The experience industry in Sweden is a relatively new concept but it is well established in the United States, primarily through the superiority of the U.S. in the film industry. In the UK the term "cultural industries" had a great impact and can now be considered to be well established. Britain has for several years been working on the concept of "creative industries" which influenced Sweden, through the Knowledge Foundation, which began the discussion on the subject. In other European countries, such as the Netherlands, there was discussion on "the cultural sector" as an important growth factor. In the U.S., the term entertainment industry is also used which has a clear relationship to the film industry. The focus here is more on the commercial interests compared to culture. In Sweden, through the Knowledge Foundation, the 
ToSEE - Tourism in Southern and Eastern Europe, Vol. 4, pp. 557-566, 2017

A. Sörensson: DEVELOPMENT WITHIN THE EXPERIENCE ECONOMY - KEY AREAS FOR

concept "creative industries" was seen too narrowly since it did not include the tourism industry (Kolmodin, 2008).

One problem is that customers are different, with different needs, and that each of them has their preference with regard to experience dimensions (Karlén, 2004). Pine and Gilmore (1998) state that two people cannot have the same experience since it is cocreated as an interaction between the staged event and the individual's state of mind. Gummesson (2007) argues that a car will be used by different customers in different ways and therefore the experience in value is different. There is also a difference between the supplier's value chain and the customer's value chain, despite the fact that they both lead to co-creation of a value for the customer. Oh, Fiore and Jeoung (2007, p. 119) argue that "tourist destinations are beginning to be positioned as experiences...tourism destinations are viewed as a means to stage the authenticity that cannot be found in the tourist's daily life". Pine and Gilmore (1999) argue that the experience economy as a paradigm is at an initial stage within a large range of industries, including tourism and hospitality. At present "the experience economy concept has been introduced to the tourism literature only at an introductory conceptual level" (Oh, Fiore and Jeoung, 2007, p. 129). There is research that shows that a number of stakeholders interacting in complex systems to create experiences to tourists. The perceived value and economic development is created in collaboration between consumers, businesses, and other stakeholders. Collaboration in the experience economy can be seen as a prerequisite, since many projects require different skills in order to achieve results such as the production of a movie (Gustafsson, 2008).

Pine and Gilmore (1998) argues that there are a difference between services and experiences. "An experience occurs when a company intentionally uses services as the stage, and goods as props, to engage individual customers in a way that creates a memorable event" (Pine and Gilmore, 1998, p. 98). Prahalad and Ramaswamy (2004) discuss co-creation and its relation to experiences. It is important to "create an experience environment in which consumers can have active dialogue and co-construct personalized experiences; product may be the same but customers can construct different experiences" (Prahalad and Ramaswamy, 2004, p. 8). Prahalad and Ramaswamy (2000) see the customer as not a passive audience but instead active players (Payne, Storbacka and Frow, 2007).

Since 2004, the service-dominant logic (S-D Logic) has been the new perspective on service among researchers (Vargo and Lusch, 2004; Maglio and Spohrer, 2007; Grönroos, 2008). The perspective has been discussed and developed and there are both those that agree and disagree about its foundation. There is still no consensus among the service researcher and therefore no widely accepted definition on service (Spohrer, Maglio, Bailey and Gruhl; 2007). Definitions of service have had a focus on "paying for performance" but also the customer plays a key role in coproduction activities and in the co-creation of value (Spohrer and Maglio, 2006; Vargo and Lusch, 2004).Vargo and Lusch (2004) discuss that goods and products cannot be separated from service, it is the final value for the customer that is what a firm is selling. There have yet not been many conducted studies that combine the S-D logic perspective as well as service science with the experience economy. Vargo and Lusch (2004) argues that there has been a paradigm shift within the marketing field where the term "service" has gotten a 
ToSEE - Tourism in Southern and Eastern Europe, Vol. 4, pp. 557-566, 2017

A. Sörensson: DEVELOPMENT WITHIN THE EXPERIENCE ECONOMY - KEY AREAS FOR

new meaning. In the traditional service marketing there has been a difference between products and service. Vargo and Lusch (2004) define service as "the application of specialized competences". "It is important to note that S-D logic uses the singular term, "service", which reflects the process of doing something beneficial for and in conjunction with some entity, rather than units of output - immaterial goods - as implied by the plural "services" (Vargo and Lusch, 2008). Vargo and Lusch (2004, $2007,2008)$ argue that all offers are services which mean that the entire management must be included in the work. In this sense all employees become service delivers of the value to the customer (Bjurklo, Edvardsson and Gebauer, 2009). Services are not only a business of its own, the same way as the hotel industry should not only be looked upon as a service industry. The S-D logic also argues that there are several steps in the supply chain but it is the final value for the customer that is central. Products are only valuable if they are used and are therefore a distribution mechanism for the services, like buying a bed to a hotel but it is a good night sleep the guest is looking for (Vargo and Lusch, 2004, 2007, 2008; Kristensson, 2009). Lusch and Vargo (2006) argue that it is experiences that are S-D logics offering to the customer. Pine and Gilmore (1998) mean that the experiences must be memorable for the customer.

\section{RESEARCH DESIGNT}

The study takes an exploratory approach and uses qualitative methodology (Glaser and Strauss, 1967; Eisenhardt, 1989). The data was collected using an electronic questionnaire with 17 questions, both open and closed questions. The questions in the questionnaires was constructed based on previous research (Pine and Gilmore, 1999; KK-stiftelsen, 2002). The county Administrative Board in Jämtland had a database with e-mail addresses to companies which was used to send the questionnaire. It was sent to 270 different companies and was answered by 136 (51\% response rate). The data was then analysed and categorized with an interpretative approach.

\section{FINDINGS AND DISCUSSION}

The respondents state that tourism is the key area for growth and the area that has the strongest possibility to compete with other products and services internationally. They also argue that experiences are creative and create an added value for the customer. One important result is that the respondents see the customer as co-creator of the experience (Vargo and Lusch, 2004; Kristensen, 2009). The customer should receive a value that they normally do not experience in their day to day life and therefore creates memories. (Pine Gilmore, 1999; Vargo and Lusch, 2004) The result from the study shows that the people from the firms see several important factors that can contribute to growth within the experience economy. 
ToSEE - Tourism in Southern and Eastern Europe, Vol. 4, pp. 557-566, 2017

A. Sörensson: DEVELOPMENT WITHIN THE EXPERIENCE ECONOMY - KEY AREAS FOR ...

\subsection{Entrepreneurs}

One of the main factor that can contribute to growth within the experience economy is the need for entrepreneurs. Entrepreneurs have for decades been and are still an important factor for growth (von Friedrichs and Boter, 2009). In this particular study with a focus on the experience economy it is still an important factor for growth despite that this is a different sector compared to traditional industries. Some respondents even pointed out the importance of entrepreneurship even in schools in order to contribute to growth since they are the next generations of entrepreneurs (Lordkipanidze et al, 2005). Entrepreneurship is an important factor for growth within the experience economy in the future. We need committed people who want to develop the experience industry, and especially the tourism industry. These people's creativity and innovative ideas should be supported. It is also important to let these innovators and entrepreneurs gain better access to test their wings through their business ideas.

\subsection{Co-operation}

Among the respondents, co-operation was another important factor for growth within the experience economy. Co-operation is important since many projects needs different competences to get result for instance a movie production (Gustafsson, 2008). It is the same situation at a tourism destination where the tourist meets many different tourist producers that together co-creates final value to the customer; the tourism experience. Since tourism are seen as the key industry with the largest possibility for growth it become an important area to address. Networks are important in the experience economy and actors co-operates in complex networks to create experiences to the customers. The level of co-operation can vary from low to high and in some cases it is more interaction, not just co-operation. (Gustafsson, 2008)

\subsection{Infrastructure}

It is also important to have well-functioning infrastructure in order to get the continued development in the experience industry. There should be quick connections, communications, and improved infrastructure according to the respondents in the survey. Lordkipanidze, Brezet and Backman (2005) argue that the government play a central role in providing the necessary physical infrastructure for business. There is also a need for arenas to host larger events. Events, primarily sports events, are often strong incentives to create new arenas for experiences. Significant investments are often made in connection with major events. For example, the Globe Arena in Stockholm, and the investments made in Åre for the Alpine World Championships are just two examples (Sahlberg, 2004). The survey lifted the importance of stadiums as an important driving force for the development of the creative industry. As well the events an important part of the concept of experience to continue to develop, especially in regions where the events organized to a large extent. One respondent stated: "It is important that Jämtland continues to organize major events such as the Alpine World Championships and the Biathlon World Cup, maybe the Olympics, so that we continue to be visible in the world. Can you also attract financially strong investors, it helps." 
ToSEE - Tourism in Southern and Eastern Europe, Vol. 4, pp. 557-566, 2017

A. Sörensson: DEVELOPMENT WITHIN THE EXPERIENCE ECONOMY - KEY AREAS FOR ...

\subsection{Businessmen and businesswomen}

Businessmen and businesswomen are also important for growth, the same way as entrepreneurs. It is at the end the business men and women that run the firms within the experience economy. There is also a strong need to support them. Many need support when they have a business idea but not the resource to start the firm. The business people in the experience economy are those that run the companies. These many private small scale business people is was to focus on. Some of the respondents believe that lower taxes is needed. One respondent stated: "Above all, make it easier for these business people and provide support to new entrepreneurs or prospective entrepreneurs about the business concept and the establishment of the company." It was also discussed that the region can receive EU funding and there should be a support system for small sized firms to get help to apply for this EU funding.

\subsection{Resources}

An important driver for development within the experience economy is resources (e $\mathrm{g}$ financial resources). The primary resource that is highlighted is venture capital. There is a need for both venture capital locally and regionally in order to invest in the future. Furthermore, economic resources should be redistributed in a way that benefits the prerequisites for development. The Knowledge Foundation has previously noted that venture capital is scarce in Sweden and applies to both start-up and development of pioneering products and services (Lagerholm \& Sjögren, 2005).

\subsection{Support from public actors}

The respondents state that the government has an important role to play to create growth. There is a need for a commitment and a will to invest in competence among these experience producers. One example is the need for strategic tourism development at different destinations. That means that everyone needs to be involved; from the government, to counties and regions, to destinations with tourist producers. By cooperation and a common concentration, it is easier to find both geographical as well as thematic development areas to invest in what every region is good in. Another important issue is that there is a need, according to the respondents, to increase the competence among the governmental staff. It is easier for them to understand growth within the production sector but harder within the experience economy. Through knowledge it might get easier for understanding what are the needs within this sector and how can we help them from a governmental point of view? Another study has shown that companies think that the biggest obstacle for growth within the experience industry is the administration (Kolmodin, 2008). There are certain aspects concerning the public system highlighted by the majority of respondents in terms of gaps in the public system to bring about a stronger growth in the experience industry. The main point highlighted are that there are problems with bureaucracy and also lack of knowledge. The actors within the public system are also focus on a short term and have an old perspective. Many are elder and have issues understanding this new type of industry (experience) rather than for instance classic steel industries. There is also a need for cooperation and coordination with a common strategy. There is also a lack of funding and resources and absence of interest among public actors. 
ToSEE - Tourism in Southern and Eastern Europe, Vol. 4, pp. 557-566, 2017

A. Sörensson: DEVELOPMENT WITHIN THE EXPERIENCE ECONOMY - KEY AREAS FOR ...

\section{CONCLUSIONS}

The aim with this article was to explore how business people believe growth can be achieved within the experience economy. They have focused on six different factors which are entrepreneurs, co-operation, resources, infrastructure, business people and support from the public sector. The six identified factors are based on both on literature as well as the results from the questionnaires. This study should been as a small step on research within the experience economy but should not be generalized. The result is rather showing indications and there is a need for continued studies within this field. The practical implications from this study are mainly for policy makers and governmental decision makers.

Morgan, Elbe and Curiel (2009) discuss that there is a need to distinguish between experiences that are unique to a particular location and those that can be everywhere. This could be discussed based on the result from this study where there are establish tourism destinations and that is also what the respondents see as the area with largest potential for growth. Morgan, Elbe and Curiel (2009, p.201) argue that "the experience economy concept is closely related to tourism both in its orgins and its implications". The customer goes from being passive to an active participant in the experience (Vargo and Lusch, 2004; Morgan, Elbe and Curiel, 2009). Russell and Faulkner (2004) have shown the importance of the underlying condition present at the particular time. In this particular study, tourism is discussed as an important area for growth within the experience economy. The underlying conditions is that the region see tourism as a main industry for the area, and therefore see potential growth. The importance of the environment for entrepreneurial performance is addressed by researcher as well (Lerner and Haber, 2001).

Campelo et al. (2014) argue that a place is experienced both by being in as well as being with. The place is therefore influenced by physical, historical, social and cultural aspects that together is creating a shared sense of place. In this study, the result shows that the region's focus area (e g tourism) is what is seen as most important for obtaining growth within the experience economy. Ek et al. (2008) have stressed out that the experience economy is complex economies like a whole city or even region. This is in line with what this study has shown. The businesspeople see tourism as a key area for growth and in order to achieve such a growth there is a need for many different actors that works together. As the study has shown you need six different factors to work together (e g entrepreneurs, co-operation, resources, infrastructure, business people and support from the public sector).

The experience economy as well as the Service Dominant-Logic are both addressing the issue of the customer seeking experience and that the customer must be an active co-creator when creating experiences. It therefore become crucial to try to know what the customers are seeking when searching for experiences. This study addresses how business people believe that experience economy can grow but is not addressing the issue from the customers' perspective. This paper helps mainly politicians to better know what kind of factors that are believed by the firms to create growth within the experience economy within a specific region. The main area within the experience 
ToSEE - Tourism in Southern and Eastern Europe, Vol. 4, pp. 557-566, 2017

A. Sörensson: DEVELOPMENT WITHIN THE EXPERIENCE ECONOMY - KEY AREAS FOR

economy is the area believed by the business people to have the greatest growth potential.

The value of this study is that is show the importance of cooperation between many different actors. It is not possible to obtain growth if not many people work together in creating experiences in the region. This study can therefore be helpful for destination management organizations that can show the importance of having several actors on board when working for development of a region.

\subsection{Further research}

It would be interesting to compare regions in Sweden and see if the people see the potential in growth, the same way as the respondents did in this particular study. In this study, tourism is one main industry and the respondents see growth potential. It would also be interesting to compare different regions and countries in terms of how the national culture influence.

\section{REFERENCES}

Abbasian, S. Bildt, C. (2007), Kvinnors egenföretagande inom upplevelseekonomin. Stockholm: Arbetslivsinstitutet.

Almqvist, K. Daal, C. (2002), Upplevelseindustrin i Sverige 2002 - Näringsliv och utbildningar. KKstiftelsen

Almquist, K. Engström, M. Olausson, K. (2000), Blandade upplevelser. KK-stiftelsen.

Bjurklo, M. Edvardsson, B. Gabauer, H. (2009), "The role of competence in initiating the transition from products to service", Managing Service Quality, Vol, 19. No, 5. pp. 493-510. doi: http://www.emeraldinsight.com/doi/full/10.1108/09604520910984346

Campelo, A., Aitken, R., Thyne, M., \& Gnoth, J. (2014), "Sense of place: The importance for destination branding", Journal of Travel Research, 53(2), 154-166. doi: http://journals.sagepub.com/doi/abs/10.1177/0047287513496474

Ek, R., Larsen, J., Hornskov, S. B., \& Mansfeldt, O. K. (2008), "A dynamic framework of tourist experiences: Space-time and performances in the experience economy", Scandinavian Journal of Hospitality and Tourism, 8(2), pp, 122-140. doi: http://www.tandfonline.com/doi/abs/10.1080/15022250802110091

Gilmore, J. Pine, J. (2002a), "Differentiating hospitality operations via experiences: why selling services is not enough", The Cornell Hotel and Restaurant Administration Quarterly. Vol, 43. No, 3, pp. 87 96. doi: https://doi.org/10.1016/S0010-8804(02)80022-2

Gilmore, J. Pine, J. (2002b), "Customer experience places: the new offering frontier", Strategy \& Leadership, Vol, 30. No, 4. pp. 4-11. doi: http://www.emeraldinsight.com/doi/full/10.1108/10878570210435306

Grönroos, C. (2008), "Service logic revisited: who creates value? And who co-creates?", European Business Review, Vol. 20, No. 4, pp. 298-314. doi: https://doi.org/10.1108/09555340810886585

Gummesson, E. (2007), "Extending the service-dominate logic: from customer centricity to balanced centricity", Journal of the Academic Marketing Science, Vol. 36, pp. 15-17. doi: https://link.springer.com/article/10.1007/s11747-007-0065-x

Gummesson, E. Lusch, R. Vargo, S. (2010), "Transitioning from service management to service-Dominan logic - observations and recommendations", International Journal of Quality and Service Science; Vol, 2. No, 1. pp. 8-22. doi: http://www.emeraldinsight.com/doi/full/10.1108/17566691011026577

Gustafsson, N. (2008), Upplevelseindustrin - marknadens logik och organisatoriska förutsättningar. En teoretisk genomgång av sektorns grundläggande struktur. ITPS. PM 2008:005.

Karlén, J. (2004), Tio år med Astrid Lindgrens Värld - tankar om turism och upplevelseindustri. Vimmerby: VTT Grafiska Vimmerby. 
ToSEE - Tourism in Southern and Eastern Europe, Vol. 4, pp. 557-566, 2017

A. Sörensson: DEVELOPMENT WITHIN THE EXPERIENCE ECONOMY - KEY AREAS FOR ...

The Knowledge Foundation. KK-stiftelsen (2002), Upplevelseindustrin i Sverige - näringsliv och utbildningar.

Kolmodin, A. (2008), Kreativ tillväxt? En rapport om "kreativa näringar" i politik och statistik. ITPS. Regleringsbrev 7, 2007. Dnr 1-101-2007/0027.

Kristensson, P. (2009), Den tjänstedominanta logiken - innebörd and implikationer för policy. Vinnova rapport. VR 2009:07.

Lerner, M. Haber, S. (2001), "Performance factors of small tourism ventures - the interface of tourism, entrepreneurship and the environment", Journal of business venturing, Vol, 16. Issue 1, pp. 77 100. doi: https://doi.org/10.1016/S0883-9026(99)00038-5

Lordkipanideze, M. Brezet, H. Backman, M. (2005), "The entrepreneurship factor in sustainable tourism development", Journal of cleaner production, Vol. 13, pp. 787-798. doi: https://doi.org/10.1016/j.jclepro.2004.02.043

Lovelock, C. Gummesson, E. (2004), "Whither Service Marketing? In Search of a New Paradigm and Fresh Perspective", Journal of Service Research, Vol, 7. No, 1. pp. 20-41. doi: http://journals.sagepub.com/doi/abs/10.1177/1094670504266131

Lusch, S. Vargo, R. (2006), "Service-dominate logic: reactions, reflections and refinements", Marketing Theory, Vol, 6. No, 3. pp. 281-288. doi: http://journals.sagepub.com/doi/abs/10.1177/1470593106066781

Maglio, P. Sphorer, J. (2008), "Fundamentals of service science", Journal of the Academy of Marketing Science, Vol. 36, pp. 18-20. Doi: https://link.springer.com/article/10.1007/s11747-007-0058-9

Morgan, M. Elbe, J. Curiel, J. (2009), "Has the Experience Economy Arrived? The Views of Destination Managers in Three Visitor-dependent Areas", International Journal of Tourism Research, Vol. 11, pp. 201-216. doi:10.1002/jtr.719

Payne, A. Storbacka, K. Frow, P. (2007), "Managing the co-creation of value", Journal of the Academy of Marketing Science, Vol, 36. No, 1. pp. 83-96. doi: https://link.springer.com/article/10.1007/s11747-007-0070-0

Pine, J. Gilmore, J. (1998), "Welcome to the Experience Economy", Harvard Business Review, Vol, 76. No, 4. pp. $97-105$.

Pine, J. Gilmore, J. (1999), The Experience Economy. Boston: Harvard Business School Press.

Prahalad, C.K. Ramaswamy, V. (2000), "Co-opting Customer Competence”, Harvard Business Review, Vol, 78. No, 1, pp. 79-87. ISSN: 0017-8012

Prahalad, C.K. Ramaswamy, V. (2004), "Co-creation experiences: the next practice in value creation", Journal of Interactive marketing, Vol, 18. No, 3. pp. 5-14. doi: https://doi.org/10.1002/dir.20015

Richards, G. (2001), The Experience Industry and the Creation of Attractions. Richards, G. (ed). In Cultura Attractions and European Tourism. UK: CABI Publishing.

Russell, R. Faulkner, B. (2004), "Entrepreneurship, chaos and the tourism area lifecycle", Annals of tourism, Issue 3, pp. 556-579. doi: https://doi.org/10.1016/j.annals.2004.01.008

Oh, H. Fiore, A. Jeoung, M. (2007), "Measuring Experience Economy Concept: Tourism Applications", Journal of Travel Research, Vol, 46. No, 2. pp. 199-132. doi: http://journals.sagepub.com/doi/abs/10.1177/0047287507304039

Parasuraman, A. Zeithaml, V.A. Berry, L.L. (1985), "A Conceptual Model of Service Quality and Its Implications for Future Research", The Journal of Marketing, Vol. 49, pp. 41-50. doi: $10.2307 / 1251430$

Sahlberg, B. (2004), Rötter, riter och roller. Östersund Etour: SNS förlag.

Spohrer, J. Anderson, L. Pass, N. Ager, T. Gruhl, D. (2008), "Service Science", Journal of Grid Computing, Vol, 6. pp. 313-324.

Spohrer, J. Maglio, P. (2006), "The Emergence of Service Science: Toward Systematic Service Innovation to Accelerate Co-Creation of Value", Production and Operations Management, Vol. 17, No. 3, pp 238-246. doi: 10.3401/poms.1080.0027

Spohrer, J. Maglio, P. Bailey, J. Gruhl, D. (2007), Steps Toward a Science of Service Systems. IEEE Computer Society. doi: 10.1109/MC.2007.33

Vargo, S. L., Lusch, R. F. (2004), "Evolving to a New Dominant Logic for Marketing", The Journal of Marketing, Vol. 68, No. 1, pp. 1-17. doi: https://doi.org/10.1509/jmkg.68.1.1.24036

Vargo, S. Lusch, R. (2008), "Service-dominate logic: continuing the evolution", Journal of the Academic Marketing Science,Vol, 36. pp. 1-10. doi: https://link.springer.com/article/10.1007/s11747-007 0069-6

Von Friedrichs, Y. Boter, H. (2009), "Meeting radical change and regional transition: regional closedowns and the role of entrepreneurship", Managing Global Transitions, Vol. 7, No. 2, pp. 99-122. 
ToSEE - Tourism in Southern and Eastern Europe, Vol. 4, pp. 557-566, 2017

A. Sörensson: DEVELOPMENT WITHIN THE EXPERIENCE ECONOMY - KEY AREAS FOR ...

Anna Sörensson, $\mathrm{PhD}$

Mid Sweden University,

Department of Economic Sciences and Law

EVJ, 83125 Östersund, Sweden

Phone: +46 705774202

E-mail: anna.sorensson@miun.se 